\title{
Competitiveness of the agrarian business in the context of maintenance of leadership positions on the market
}

\author{
Tetiana Shestakovska \\ Chernihiv National Technological University \\ Shevchenka str. 95, 14000, Chernihiv \\ Ukraine \\ e-mail: Shestakovska27@gmail.com \\ Nino Durglishvili \\ Ivane Javakhishvili Tbilisi State University \\ Ilia Chavchavadze Ave. 8, 0179, Tbilisi \\ Georgia \\ e-mail: nino.durglishvili@tsu.ge \\ Svetlana Kushnir \\ Department of Finance, Banking and Insurance \\ Zaporizhzhya National University \\ Zhukovskogo str. 66, 69600, Zaporizhzhya \\ Ukraine \\ e-mail: svetlanaak@ukr.net
}

\begin{abstract}
This paper presents the features of ensuring an adequate level of competitiveness of agrarian business with the aim of forming leadership positions both in the domestic and world markets, which will contribute to satisfying the needs of consumers and food security of the country. The paper systemizes the views of the scientists for determining the content of agrarian business competitiveness. Moreover, the paper grounds its own approach to these issues.

The paper identifies the problems of competitiveness of modern agrarian business The authors clarify that the decline of the country's leading position on the competitiveness of agrarian production is associated with an unstable socio-economic and political situation. By means of a structural and structural-functional analysis, the innovative and institutional components of ensuring the competitiveness of Ukrainian agrarian business in the long-term perspective are determined. The institutional imperatives that provide the agrarian business with an appropriate vector of development and reveal opportunities for increasing competitiveness, are offered which create additional leadership in the agrarian market.
\end{abstract}

\section{Introduction}

In modern economic conditions, every subject of agrarian business is trying to take a profitable market niche, keep its positions for as long as possible and gradually become a leader among other commodity producers, using its competitive advantages (Mikhaylov 2018). The aggravation of competition in the markets of agri-food products is conditioned by their liberalization and internationalization, rapid innovation and technological development of agrarian business, active activity of vertically and horizontally integrated structures (Jankelová et al. 2017; Tireuov et al. 2018). Ukraine has considerable potential for the development of spheres of agrarian business, which is due to natural geographic factors, traditions of agricultural production, resource supply, subjects of the domestic agricultural sector. However, in the conditions of insufficient solvency of the population, the provision of consumer demand for certain groups of goods takes place at the expense of imports. As practice has shown, most Ukrainian subjects in agrarian business are not ready for active competition. And, however, a way out of a difficult economic situation can only be the creation of a competitive production oriented to the needs of consumers. And in this sense, competitiveness is a condition for the survival of domestic subjects in the agrarian business (Moskalenko and Yevsieieva 2015; Abrham et al. 2015; or Gryshova et al. 2016a, 2016b). The agrarian business in Ukraine are encouraging the search for the directions that will contribute to the formation of a sustainable system for maintaining the competitiveness of agricultural producers and stabilizing their market leadership positions. One of the main instruments for achieving this goal is to increase the production of quality and environmentally friendly products, to promote it in the consumer market at affordable prices for different sectors of the population, which will ensure the competitiveness of a domestic agricultural busines. 


\section{Literature review}

For the first time, the concept of "competitiveness" was introduced at the end of the 1970s by Porter (2001), who, in a competitive manner, takes profitability and productivity of using the resources. Competitiveness characterizes the indicators of cost, profitability of products, yield capacity productivity of manufacturing, productivity of labour (Porter 2001). To them, individual authors add more profitability, productivity, turnover, business activity and liquidity (Rossikhina 2010; Tarnavska 2008; Fathutdinov 2004; Pyatnitskaya at al. 2014). According to (Grishova at al. 2016): "... the competitiveness of the economy is a necessary prerequisite for the equal participation of the state in international cooperation". Therefore, it is important in the methodological perspective to consider competitiveness as a multi-level concept.

According to Mitiay (2015), the category of "competitiveness of agrarian business" should be ensured by such indicators as high production efficiency, which is realized thanks to modern equipment, technologies, qualified personnel and the ability to conquer and maintain its own market niche for a long time which is realized through the effective use of the principles of marketing management.

In the works of Frohberg and Hartmann (1997): "competitiveness is an indicator of the ability to deliver goods and services in that location, form and at a time when they are needed by buyers, at a price not worse or better than the potential competitors have, while incomes at least correspond to the alternative cost of the resources used in the process of production".

The concept of the competitiveness of agrarian business is much more complicated and interpreted ambiguously. Gerasimchuk and Kovalska (2008) consider the competitiveness of the agrarian business as "the ability to maintain or expand competitive positions in the target market in the process of adaptation to a changing competitive environment of functioning through the ratio of the price / the quality of products as a point of intersection of the interests of the manufacturer and the consumer, indicating the moment of consistency between the offer and demand. Ensuring consistency contributes to maximizing profits by producing safe and highquality agricultural products and achieving competitive advantages of agricultural enterprises" (Gerasimchuk and Kovalska 2008).

The concepts of competitiveness of the agrarian business are quite fully and systematically revealed in the definition of Malik and Nuzhna (2007) «In their opinion - this is the ability of the economic subjects in the agrarian sphere to adapt to the new conditions of management to use their competitive advantages and win in competition in the markets of agricultural products and services, to maximize the efficient use of land resources, to fully meet the needs of the buyer by analyzing the structure of the market and flexibly react to the change of its conjuncture» ( Malik and Nuzhna 2007).

The competitiveness of the subjects of agrarian business has the characteristic features connected with: a) the specificity of agriculture as a type of economic activity; b) a significant level of rivalry among the agricultural producers; c) a significant number and diversity of the subjects of agrarian business. In general, the competitiveness of the subjects of agrarian business can be defined in the context of its leading position with respect to other subjects in the area within the country and beyond (Filipishyna et al. 2018).

Moreover, Kryuchkova (2016) considers competitiveness of agrarian business "as a system of characteristics of an agrarian enterprise, which determines its potential opportunities in the market of agrarian products and services, the possibility of the efficient use of land, labor and financial resources and adaptation to new economic conditions" (Kryuchkova 2016).

Agreeing with the opinion of Goncharenko (2012), we believe that the innovative and institutional component of the competitive development of the subjects of agricultural business is a key one and it directly influences the leading market positions of agrarian business (Goncharenko 2012). Lopatinsky and Kifjak (2014) emphasize the considerable social significance of forming an effective innovative mechanism for ensuring the competitiveness of agrarian business, taking into account the socio-economic and cultural heritage of past transformations and advanced foreign experience. Thus, the competitiveness of agrarian business in modern conditions is ensured on the basis of a well-developed innovative strategy aimed at high effective activity in the direction of meeting the needs of consumers

\section{The purpose and methods}

It is intended to justify the essence of the competitiveness of agrarian business, to identify the problems and promising directions of raising the level of competitiveness of the subjects of agricultural business in order to ensure stable leading positions and to form strategic opportunities for the access to world markets for domestic agricultural producers. During the research, the following scientific methods were used: analysis and synthesis (to identify the problems of ensuring competitiveness), theoretical search and abstract-logical (to characterize the essence and characteristics of competitiveness of the agrarian business), structural and structural-functional analysis (for carrying out the strategic directions for the development of competitiveness of agrarian business in the context of retaining the leading positions in the modern market). 


\section{Results and discussions}

The processes of globalization of the economy, increasing the degree of openness of the national economy, requires the formation of an effective mechanism for ensuring the competitiveness of agrarian business in order to gain leading position in the world market, which is characterized by certain features: rivalry - competitiveness is considered concerning not only domestic but also foreign enterprises; alternative choice - globalization processes will allow to cross borders freely not only for products, but also for resources; the expansion of the factors of external influence - the factors of influence are expanding due to the outbreak of rivalry beyond the boundaries, thus affecting the competitiveness of enterprises in the world market; adaptation criteria - the process of globalization requires from agrarian business to create a mechanism for adaptation and select its new criteria; the process of technological upgrading - the competitiveness of products leads to increased mobility of resources, through constant technological upgrades due to the introduction of innovations; the creation of new methods management - increasing the competitiveness of products requires the development of new management methods that allow taking into account new factors of the competitive environment and accelerate the adoption of management decisions (Gryshova and Shestakovska 2017; Lopatinsky at al. 2014).

The determining indicator of the competitiveness of domestic agricultural business is the state's position in global ratings. In total, there are about ten international indexes. The dynamics of the external vision of economic change in Ukraine in the period of 2010-2016 from the positions of international rating is given in Table 1.

Table 1. Ukraine's position in international ratings

\begin{tabular}{|l|c|c|c|c|c|c|c|}
\hline \multirow{2}{*}{ Name of the rating } & \multicolumn{9}{|c|}{ Ukraine's rank in ratings } \\
\cline { 2 - 8 } & $\begin{array}{c}\mathbf{2 0 1 0 -} \\
\mathbf{2 0 1 1}\end{array}$ & $\begin{array}{c}\mathbf{2 0 1 1 -} \\
\mathbf{2 0 1 2}\end{array}$ & $\begin{array}{c}\mathbf{2 0 1 2 -} \\
\mathbf{2 0 1 3}\end{array}$ & $\begin{array}{c}\mathbf{2 0 1 3 -} \\
\mathbf{2 0 1 4}\end{array}$ & $\begin{array}{c}\mathbf{2 0 1 4 -} \\
\mathbf{2 0 1 5}\end{array}$ & $\begin{array}{c}\mathbf{2 0 1 5 -} \\
\mathbf{2 0 1 6}\end{array}$ & $\begin{array}{c}\mathbf{2 0 1 6 -} \\
\mathbf{2 0 1 7}\end{array}$ \\
\hline $\begin{array}{l}\text { Index of global } \\
\text { Competitiveness }\end{array}$ & 89 & 82 & 73 & 84 & 76 & 79 & 85 \\
\hline Index of conducting business & 147 & 149 & 152 & 137 & 112 & 96 & 83 \\
\hline Index of Economic Freedom & 162 & 164 & 163 & 161 & 155 & 162 & 166 \\
\hline $\begin{array}{l}\text { Index of investment } \\
\text { attractiveness }\end{array}$ & 2,57 & 3,28 & 2,18 & 2,12 & 1,87 & 2,57 & 2,88 \\
\hline
\end{tabular}

Source: Edclub (2016)

The factors that have mostly affected the deterioration of the situation include corruption, political instability, inflation, and the ineffectiveness of public policy (Table 2).

Table 2. Analysis of the dynamics of the main indexes of the global competitiveness index of Ukraine during 2010-2016

\begin{tabular}{|c|c|c|c|c|c|c|c|}
\hline \multirow[t]{2}{*}{ Index Component } & \multicolumn{7}{|c|}{ Place of Ukraine } \\
\hline & $\begin{array}{l}2010- \\
2011\end{array}$ & $\begin{array}{l}2011- \\
2012\end{array}$ & $\begin{array}{l}2012- \\
2013\end{array}$ & $\begin{array}{l}2013- \\
2014\end{array}$ & $\begin{array}{l}2014- \\
2015\end{array}$ & $\begin{array}{l}2015- \\
2016\end{array}$ & $\begin{array}{l}2016- \\
2017\end{array}$ \\
\hline Basic requirements & 102 & 98 & 79 & 79 & 87 & 101 & 102 \\
\hline Market size & 38 & 38 & 38 & 38 & 38 & 45 & 47 \\
\hline Infrastructure & 68 & 71 & 65 & 68 & 68 & 69 & 75 \\
\hline Macroeconomic stability & 132 & 112 & 90 & 107 & 105 & 134 & 128 \\
\hline $\begin{array}{l}\text { Efficiency of the market of } \\
\text { goods and services }\end{array}$ & 129 & 129 & 117 & 124 & 112 & 106 & 108 \\
\hline Labor market efficiency & 54 & 61 & 62 & 84 & 80 & 56 & 73 \\
\hline $\begin{array}{l}\text { The level of development } \\
\text { financial market }\end{array}$ & 119 & 116 & 114 & 117 & 107 & 121 & 130 \\
\hline Competitiveness of business & 100 & 103 & 91 & 97 & 99 & 91 & 98 \\
\hline Innovation and development & 88 & 93 & 79 & - & 92 & 72 & 73 \\
\hline
\end{tabular}

Source: Ministry of Agricultural Policy and Food of Ukraine (2017)

The fundamental basis for resolving the national food security and competitiveness of our state should be the stable development of agrarian business and the constant increase of production of agricultural products and foodstuffs. The results of the functioning of agrarian business are changing very dynamically, as evidenced by a comparative assessment of its main indicators (Table 3 ).

The agrarian sector failed to maintain the positive dynamics of previous years: in 2015, the agricultural production index compared to 2014 was $95.2 \%$. At the same time in crop production the output for the period decreased by $5.2 \%$, in livestock production - by $3.7 \%$. 
Table 3. Macroeconomic indicators of the competitiveness of agrarian business in Ukraine

\begin{tabular}{|c|c|c|c|c|c|c|c|}
\hline \multirow{2}{*}{ Indexes } & \multicolumn{6}{|c|}{ Years } & \multirow{2}{*}{$\begin{array}{l}\text { The pace of } \\
\text { growth, } \\
2015 / 2010\end{array}$} \\
\hline & 2010 & 2011 & 2012 & 2013 & 2014 & 2015 & \\
\hline $\begin{array}{c}\text { The share of agricultural } \\
\text { production in the total gross } \\
\text { value added, in \% }\end{array}$ & 9,6 & 9,4 & 9,0 & 9,9 & 11,8 & 11,2 & 116,7 \\
\hline $\begin{array}{l}\text { The index of prices of sales of } \\
\text { agricultural products (December } \\
\text { to December of the previous } \\
\text { year), } \%\end{array}$ & 130 & 113,6 & 106,8 & 97,1 & 124,3 & 154,5 & 118,8 \\
\hline $\begin{array}{l}\text { Gross output at constant prices, } \\
\text { UAH billions }\end{array}$ & 194,9 & 233,7 & 223,3 & 252,9 & 251,4 & 248,6 & 127,5 \\
\hline $\begin{array}{c}\text { Gross output per one employee, } \\
\text { UAH }\end{array}$ & 132680 & 165229 & 159679 & 201217 & 227753 & 223309 & 168,3 \\
\hline $\begin{array}{c}\text { The index of agricultural } \\
\text { production, } \%\end{array}$ & 98,5 & 119,9 & 95,5 & 113,3 & 102,2 & 95,2 & 96,4 \\
\hline $\begin{array}{c}\text { The level of profitability of } \\
\text { production, } \%\end{array}$ & 24,5 & 24,7 & 22,8 & 11,7 & 21,1 & 22,6 & 92,2 \\
\hline $\begin{array}{l}\text { The volume of capital } \\
\text { investments in agriculture, UAH } \\
\text { billions }\end{array}$ & 8,82 & 13,50 & 15,62 & 16,05 & 17,14 & 27,9 & 316,3 \\
\hline $\begin{array}{l}\text { The export of agri-food products, } \\
\text { UAH billions }\end{array}$ & 78,9 & 102,4 & 142,9 & 136,1 & 198,1 & 204,7 & 259,4 \\
\hline
\end{tabular}

Source: Ministry of Agricultural Policy and Food of Ukraine (2017)

The agrarian sector failed to maintain the positive dynamics of previous years: in 2015, the agricultural production index compared to 2014 was $95.2 \%$. At the same time in crop production the output for the period decreased by $5.2 \%$, in livestock production - by $3.7 \%$. Despite the decline in agricultural production, the agrarian sector remains one of the main sources of foreign exchange earnings in the country. In 2015 the positive balance of foreign trade in agroindustrial complex amounted to 11.1 billion of the US dollars. The export of agricultural products was at level of \$ 14.6 billion: of the US dollars, and its share in the general commodity structure of export increased to $38.2 \%$, which became the highest value during the years of independence (Figure 1).

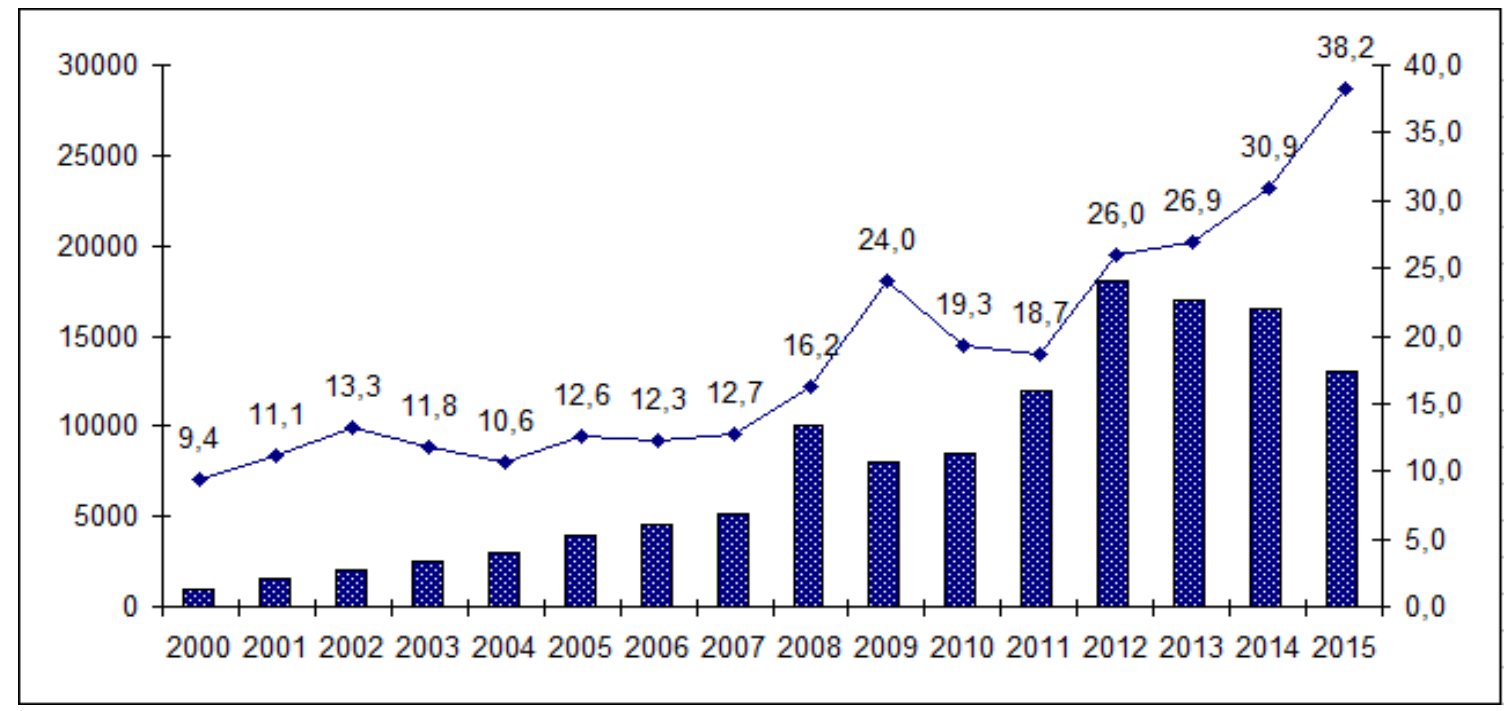

Fig. 1. Estimates of the dynamics of export of Ukraine's agrarian production in 2000-2015 Source: Ministry of Agricultural Policy and Food of Ukraine (2017)

Domestic exporters have successfully established positions in the markets of China, Israel, Egypt, other countries of Asia and the Persian Gulf. At the same time, even against the background of an increase in exports of agricultural products, Ukraine loses currency earnings due to the negative dynamics of world food prices. 
First, the land capital remains outside the economic turnover. The permanent extension of the moratorium on the sale of agricultural land does not allow the full use of financial instruments for attracting investment through a loan mechanism, since the mortgage allows for the alienation of mortgaged property (land) that can not be carried out on lease.

Secondly, preserving the imbalance in the production of certain types of agricultural products. Thus, in 2015, households have grown $98 \%$ of the total potato harvest, $86 \%$ - vegetables, $81 \%$ - fruits and berries (in $2014-97 \%, 86 \%$ and $83 \%$ respectively); as of January 1, 2016, 66.1\% of the total cattle population was kept there (by January 1, 2015 - 66.3\%) (The official site of the Ministry of Agricultural Policy and Food of Ukraine, 2017). It negatively affects the ecological state of farmland, leads to the depletion of soils, decrease of qualitative indicators of agricultural land.

Thirdly, the lack of effective state support for production and infrastructure for the sale of fruit and vegetable products, improper regulation of the internal food market, which leads to unpredictable price surges for food. In 2015, the prices for vegetable products (cabbage - 3.6 times, carrots - 3.5, onions up to 3.2, beets 2.5, potatoes - by 1.8 times) increased significantly (Ministry of Agricultural Policy and Food of Ukraine 2017). However, the reasons for this were not only adverse weather conditions for growing crops, as a result of which their gross fees decreased, but also the problems of state regulation of both price situation and production and marketing processes. First of all, the absence of state programs for supporting the development of service (including sales) cooperatives and households (as the main producers of fruit and vegetable products); slow reaction of PJSC "Agrarian Fund" on price fluctuations; orientation of the state policy on monocultural agriculture and export of raw materials.

Fourth, ineffective use of the potential of Ukrainian lands. According to the yields of all major crops, our country gives way to the leading world producers of similar products. So, if in Ukraine wheat production in 2014 was $40.1 \mathrm{c} / \mathrm{ha}$, barley $-30.1 \mathrm{c} / \mathrm{ha}$, sugar beet $-476.5 \mathrm{c} / \mathrm{ha}$, potatoes $-176.4 \mathrm{c} / \mathrm{ha}$, then in France - 73.6, 66.5, 924.3 and 479.4 centners per hectare; Great Britain - 85.9, 64.0, 726.7 and 300.9 centners per hectare; Germany - 86.3, 73.5, 798.6 and 474.2 centners per hectare; The Netherlands - 91.7, 71.3, 908.4 and 456.6 centners per hectare, respectively (The official site of the Ministry of Agricultural Policy and Food of Ukraine, 2017).

Fifth, the lack of financial resources for the sustainable management of economic activity, by agricultural producers, the lack of investment funds, the inaccessibility of bank loans, and the low level of state support for agriculture make it difficult for farmers to access working capital needed to cover the time gap between the need for funds and the period of favorable product sales prices.

Ovearll, it becomes obvous that the volume of capital investments in agriculture, forestry and fish industry in 2015 amounted to 30.2 billion UAH, or $11.0 \%$ of their total volume in the economy (in industry - 32.1\%). Financing of the sector from the state budget remains low, in particular, in the direction "Financial support of measures in the agro-industrial complex" in 2012 was envisaged UAH 827.4 million, in 2013 - 96.8, in 2014 and 2015 - only 5 million UAH Last year, the funds provided in the areas of "Financial support of measures in the agro-industrial complex by reducing the cost of loans" and "State support to the livestock sector" in the amount of UAH 300 million and UAH 250 million respectively, were envisaged as development expenditures. Sixth, the high level of dependence of agricultural production on imports of the main types of material and technical resources, which was particularly acute in conditions of sharp devaluation of the hryvnia. Agricultural machinery in Ukraine has almost $70 \%$ import origin, and grain harvesters are exclusively imported. The share of plants of imported breeding in the Ukrainian market as a whole is estimated at $47 \%$, with sunflower - 65\%, maize - 70\%, rape $-50 \%$, and sugar beet $-90 \%$ (The official site of the Ministry of Agricultural Policy and Food of Ukraine, 2017). Plant protection products are almost entirely imported, since actual production is considered inappropriate because of the moral and technical obsolete equipment.

The agrarian business of Ukraine is able to form a leading position on the world market and provide the necessary level of competitiveness on the basis of effective participation of the state in its functioning. Accordingly, the main efforts of innovation and infrastructure development of agrarian business, having for priority stabilization of competitive domestic agricultural business and development of all spheres of agrarian relations, should be aimed at:

1) the strategic formation of an institutional mechanism with an open competitive access to resources, which will affect the reduction of the level of uncertainty of socio-economic processes and, thus, will simplify the interaction of all participants in the agrarian business, make them transparent and understandable;

2) the development of venture investment of innovative subjects of agrarian business, which, due to the introduction of new technologies will make monopoly impossible and will compete with intermediaries;

3 ) the deregulation of the functioning of the agrarian business, which involves the elimination of excessive state regulation, simplification of conditions of conducting agricultural business, promotion of investments and initiatives in the agrarian sector; 
4) the implementation of long-term specialized (non-transferable to other sectors with equal margins) investments, especially investments into improving the scientific and technological, scientific and technical basis and innovation infrastructure;

5) the stimulation and support of agrarian science and innovative clusters, aimed at the production of high-tech, competitive on the world markets products;

6) the harmonization of the interests of owners, hired workers and rural communities, which will promote the formation of socially responsible behavior among all participants in agrarian business (Fischuk at al. 2012; Svitkovska 2013; Grinciuc at al. 2017; or Strielkowski at al. 2016).

If the first stage of modernization directed at the innovative development of the agrarian sector of the economy is related to this aspect of state regulation, then in the future, with the transition from the policy of support of predetermined "national leaders" to the policy of forming an environment favourable to the independent formation of innovative companies, the effective instrument can only be the improvement of the institutes of development and the maintenance of the established institutional system and the provision of state presence. The practice of structural regulation shows that in conditions of a structural crisis and structural transformation, a significant expansion of the economic role of the state is required (Table 4).

The concentration of efforts on reorganizing the structure of the subjects of agrarian production can contribute to the stability of possible leadership positions in the context of implementation of the programs of structural national transformations. The government has sufficient opportunities to coordinate all necessary measures and optimally allocate available material, financial, labor resources, and can neutralize negative social phenomena that somehow arise in the process of radical transformations and affect the process of maintaining competitiveness in the field of agrarian business.

Table 4. Strategic directions of ensuring the competitiveness of the Ukrainian agrarian business

\begin{tabular}{|c|l|}
\hline $\begin{array}{c}\text { Institutional and structural } \\
\text { component }\end{array}$ & \multicolumn{1}{|c|}{ The main Strategic Directions } \\
\hline Structural changes in the industry & $\begin{array}{l}\text { The expansion of traditional productions caused by growing solvent } \\
\text { demand. The formation of new productions in accordance with world } \\
\text { progressive trends. The development of unique national industries in order } \\
\text { to create new competitive advantages on the domestic and world markets. } \\
\text { The creation of alternative agricultural industries using recreational and } \\
\text { cultural-historical potential of the territories of the Ukraine }\end{array}$ \\
\hline $\begin{array}{c}\text { The influence of structural } \\
\text { components of organizational and } \\
\text { economic mechanism of } \\
\text { functioning of the agrarian business }\end{array}$ & $\begin{array}{l}\text { The maintenance of multiculturalism in the countryside. The improvement } \\
\text { of the ratio of profitable and loss-making enterprises. }\end{array}$ \\
\hline $\begin{array}{c}\text { Modernization of the institutional } \\
\text { provision }\end{array}$ & $\begin{array}{l}\text { The development of all forms of business: large, medium, small. The } \\
\text { creation of equal conditions for functioning and reception of incomes, the } \\
\text { formation of an effective competitive environment and mutually beneficial } \\
\text { relations between the subjects of the rural economy. Ensuring adequate } \\
\text { proportions of state support for rural commodity producers. }\end{array}$ \\
\hline $\begin{array}{c}\text { Territorial structure } \\
\text { The progressive distribution of industrial output across the country. } \\
\text { Alignment of interregional levels of economic development of the industry }\end{array}$ \\
\hline The structure of foreign economic \\
relations & $\begin{array}{l}\text { The transition to an innovative way of development, technical and } \\
\text { technological modernization of the industry. }\end{array}$ \\
\hline $\begin{array}{l}\text { The progressive changes in the structure of import and export in the } \\
\text { industry. Maximum possible satisfaction of population`s demand for } \\
\text { foodstuffs at the expense of own resources and intensification of import } \\
\text { substitution processes. The formation of priorities and tools of foreign } \\
\text { economic and agrarian policy. }\end{array}$ \\
\hline
\end{tabular}

Source: Own results

\section{Conclusions}

The approach proposed by us comprehensively and versatile characterizes the output of the agrarian businesses to a new stage in the formation of leading positions in the market and the achievement of competitiveness in modern conditions, using innovative technologies. Domestic exporters have successfully established positions in the markets of China, Israel, Egypt, other countries of Asia and the Persian Gulf. At the same time, even against the background of an increase in exports of agricultural products, Ukraine loses currency earnings due to the negative dynamics of world food prices. First, the land capital remains outside the economic turnover. The permanent extension of the moratorium on the sale of agricultural land does not allow the full use of financial instruments for attracting investment through a loan mechanism, since the mortgage allows for the alienation of mortgaged property (land) that can not be carried out on lease. 
In connection with the existence of a set of problems ensuring the competitiveness of agrarian business, the following tasks need to be solver: to form a complex of interconnected sectoral investment and innovation programs and projects that implement the ideas throughout the chain: from fundamental research to the development of innovative market niches; to provide the scientific and scientific-technical sphere with financial and material resources in the context of effective functioning of progressive forms of public-private partnership; create an institutional environment for the implementation and introducing of innovative technologies; to strengthen the role of subjects of the agrarian business in the innovation process, to stimulate the introduction of development in production by increasing the availability of financial resources, reducing tax burden and other stabilizers; to create competitive centers of knowledge through the joining of research organizations and establishing a flexible, rapid and fruitful cooperation in various areas of innovation activity; to form a system of training, retraining and advanced training of personnel necessary for the implementation of specific innovative programs and projects, as well as civil servants involved in the regulation of the innovation process; to provide control over the use of innovations to determine their needs and compliance with environmental, technical and other requirements; to develop the methods of accounting and monitoring the impact of innovation activity on the competitiveness of the agrarian business.

\section{References}

Abrham J, Strielkowski W, Vošta M, Šlajs J (2015) Factors that influence the competitiveness of Czech rural small and medium enterprises. Agricultural Economics-Zemedelska Ekonomika 61(10):450-460. doi: 10.17221/63/2015-AGRICECON

Edclub (2016) The position of Ukraine in the world ranking according to the index of the global competitiveness 2016. $\quad$ http://edclub.com.ua/analityka/pozyciya-ukrayiny-v-reytyngu-krayin-svituza-indeksom-globalnoyikonkurentospromozhnosti-1. Accessed 20 Aug 2018

Fathutdinov RA, The Management of Competitiveness of the Organization, $1^{\text {st }}$ edn. (Exmo, Kiev, 2004), 544 p.

Filipishyna L, Bessonova S, Venckeviciute G (2018) Integral assessment of developmental stability: cases of Lithuania and Ukraine. Entrepreneurship and Sustainability Issues 6(1):87-99. doi: 10.9770/jesi.2018.6.1(7)

Fischuk VP, Lukashenko OP, Khmaruk OM (2012) The competitiveness of Agricultural Products. Collected Works of VNUU: Economic Sciences 4(70):160-164.

Frohberg K, Hartmann M (1997) Comparating Measures of Competitiveness. IAMO Duscussion Issue, No. 2.

Gerasimchuk ZV, The competitiveness of the region: theory, methodology, practice, $1^{\text {st }}$ edn. (Lutsk: Supermarket, 2008), 248 p.

Goncharenko OV (2012) The innovative development of the agrarian enterprises in the context of the formation of an information economy. Current Problems of the Economy 10(136):103-109.

Grinciuc L, Bujor T (2017) The impact of the small business in the agricultural sector in order to enhance competitiveness. Scientific Papers Series Management, Economic Engineering in Agriculture and Rural Development, 17(1):321-234

Gryshova IYu, Shestakovska TL, Glushko OV (2017) The economic measurement of convergence of institutional impact on the sustainability of development. Scientific Papers of the Legislation Institute of the Verkhovna Rada of Ukraine 4:75-80.

Gryshova IYu, Mityay OV, Gnatyeva TM (2016a) Competitiveness of agricultural enterprises as a main factor in sustainable development of agricultural sector. Ukrainian Journal of Applied Economics 2:25-35.

Gryshova IYu, Shabatura TS, Naumov OB (2016b) Capitalization of the brand as a tool for maximizing the market value of business. Scientific Bulletin Polyssia 3(6):168-175.

Gryshova, IYu, Shestakovska TL (2017) The asymmetry of the resource configuration and its destructive impact on the capitalization of agribusiness. Scientific Papers of the Legislation Institute of the Verkhovna Rada of Ukraine 2:128-133.

Jankelová N, Jankurová A, Masár D (2017) Effective management and self-government: current trends. Czech Journal of Social Sciences, Business and Economics 6(2):21-31. doi: 10.24984/cjssbe.2017.6.2.3

Kryuchkova ZhV (2016) The investigation of the Essence of the Competitiveness and the Competitiveness of the Agrarian Enterprises. Agrosvit 7:44-50. 
Lopatinsky YuM, Kifyak VI, The development of the agrarian sector of the national economy on an institutional basis, $1^{\text {st }}$ edn. (Chernivtsi National University Press, Chernivtsi, 2014), 248 p.

Malik MYa, Nuzhna OA (2007) The competitiveness of the agrarian enterprises: methodology and mechanisms, $1^{\text {st }}$ edn. (Institute of Agrarian Economics, Kiev, 2007), 270 p.

Mikhaylov AS (2018) Socio-spatial dynamics, networks and modelling of regional milieu. Entrepreneurship and Sustainability Issues 5(4):1020-1030. doi: 10.9770/jesi.2018.5.4(22)

Ministry of Agricultural Policy and Food of Ukraine (2017). Statisics. www.minagro.kiev.ua. Accessed 29 Aug 2018

Mityay OV (2015) Scientific approaches to the branches of competitiveness of agroindustrial complex. Problems and prospects of economy and management 1:82-90.

Moskalenko V, Yevsieieva I (2015) Effective leadership conflict management in food technology enterprises. International Economics Letters 4(2):91-102. doi: 10.24984/iel.2015.4.2.4

Porter M. Competition: Students`Manual, $1^{\text {st }}$ edn. (Moscow: Williams, 2001), 425 p.

Pyatnitskaya GT, Perein AM, Ryabova OV (2014) Competitive advantages of the enterprises: definition and sources of formation. Economic strategy and prospects of trade and services development 1:235-248.

Rossikhina OE (2010) The main factors of competitiveness of the enterprise. State and regions 2:184-187.

Strielkowski W, Lisin E, Gryshova I (2016) Climate Policy of the European Union: What to Expect from the Paris Agreement? Romanian journal of European affairs. 16(4):79-84.

Svitkovska AO (2013) The competitiveness of the agrarian enterprises in conditions of deepening of eurointegration relations. Investments: practice and experience 8:38-40.

Tarnavska NP (2008) The Management of Competitiveness of Enterprise: Theory, Methodology, Practice. Ternopil Economic University Press, Ternopil: Economic Thought, 2008), 570 p.

Tireuov K, Mizanbekova S, Kalykova B, Nurmanbekova G (2018) Towards food security and sustainable development through enhancing efficiency of grain industry. Entrepreneurship and Sustainability Issues 6(1): 446-455. doi: 10.9770/jesi.2018.6.1(27) 